\title{
Reprezentatywność zakładowej organizacji związkowej w świetle nowelizacji ustawy o związkach zawodowych
} Representativeness of an establishment trade union
organization in the light of novelization of an act on trade unions

dr Jakub Szmit

Uniwersytet Gdański, Katedra Prawa Pracy jszmit@prawo.ug.edu.pl ORCID: 0000-9079-4630

\begin{abstract}
Streszczenie Autor omawia i ocenia nowe rozwiązania dotyczące reprezentatywności zakładowych organizacji związkowych wprowadzone do ustawy o związkach zawodowych ustawą nowelizującą z 5 lipca 2018 r. Analizuje najważniejsze elementy związane z konstrukcją reprezentatywności na szczeblu zakładowym, tj. przesłanki nabycia reprezentatywności, informacje dotyczące liczebności organizacji związkowych oraz mechanizm uprzywilejowania organizacji reprezentatywnych. Zdaniem autora działania podjęte przez ustawodawcę w analizowanym zakresie mają charakter ewolucyjny i należy je ocenić jako pozytywne, stanowiące usprawnienie dotychczasowych regulacji.
\end{abstract}

Słowa kluczowe: związki zawodowe, reprezentatywność, zakładowa organizacja związkowa, zbiorowe prawo pracy.

Summary The article is devoted to new solutions regarding the representativeness of trade union organizations. The author presents the directions adopted in this matter in the amendment of the Trade Union Act. The analysis concerns the most important elements related to the construction of representativeness at the company level, such as the premises for acquiring representativeness, information on the size of trade union organizations and the mechanism of privileging representative organizations. The article also includes assessments of new regulations. In conclusion, the author concludes that the actions taken by the legislator in the analyzed area are of an evolutionary nature and should be assessed as positive, improving the existing regulations.

Keywords: trade unions, representativeness, establishment trade union organization, collective labour law.

JEL: K31

Str. 28-32

\section{Bibliografia}

Baran, K. W. (2018). Refleksje o ochronie stosunku zatrudnienia działaczy związkowych na poziomie zakładowym po nowelizacji ustawy związkowej z 5 lipca 2018 r. Praca i Zabezpieczenie Społeczne, (10).

Baran, K. W. (2010). Zbiorowe prawo pracy. Komentarz. Warszawa.

Hajn, Z. (1999). Status prawny organizacji pracodawców. Warszawa.

Hajn, Z. (2013). Zbiorowe prawo pracy. Zarys systemu. Warszawa.

Szmit, J. (2016). Glosa do wyroku Sądu Najwyższego z dnia 8 września 2015 r., I PK 234/14. Orzecznictwo Sądów Polskich, (12).

Żołyński, J. (2014). Ustawa o zwiąkach zawodowych. Komentarz. Warszawa 